\title{
Therapeutic conduct in postmenopausal women with different forms of urinary incontinence
}

\section{Postępowanie fizjoterapeutyczne u kobiet po menopauzie z różnymi rodzajami nietrzymania moczu}

\author{
Maria Szymczak, Marian Majchrzycki \\ Rehabilitation Chair and Clinic, Poznan University of Medical Sciences, Poznan; \\ Head of Chair and Department: Prof. Wanda Stryła
}

Przegląd Menopauzalny 2013; 6: 484-488

\section{Summary}

Urinary incontinence is a serious medical, social, economic and therapeutic issue. This paper is a review of current ideas on the influence of menopause and age on the risk of incontinence. The paper presents selected physiotherapeutic methods used in the treatment of urinary incontinence. The most commonly used methods include: urogenital diaphragm exercises (Kegel exercise), behavior therapy (biofeedback, bladder training), electrostimulation, magnetic therapy and mechanical tools (e.g. vaginal cones). The importance of patient and health professional prophylaxis is also discussed.

Key words: menopause, urinary incontinence.

\section{Streszczenie}

Nietrzymanie moczu stanowi istotny problem medyczny, społeczny, ekonomiczny i terapeutyczny. Paca ma charakter poglądowy. Przedstawiono w niej aktualne poglądy na temat wpływu menopauzy i wieku na ryzyko rozwoju inkontynecji. W pracy przedstawiono wybrane metody fizjoterapeutyczne stosowane w leczeniu nietrzymania moczu. Do najczęściej stosowanych należą: ćwiczenia mięśni przepony moczowo-płciowej (tzw. ćwiczenia Kegla), terapia behawioralna (biofeedback, trening pęcherza moczowego), elektrostymulacja, magnetoterapia i środki mechaniczne (np. ciężarki dopochwowe). Zwraca się także uwagę na rolę profilaktyki stosowanej przez pacjenta i lekarza leczącego.

Słowa kluczowe: menopauza, nietrzymanie moczu.

Menopause appears around the age of 50. Women live statistically longer than men, so the post-menopausal time lasts for around 1/3 of their life. There are more and more studies on the quality of life of women after menopause, prophylaxis of cardiovascular health and osteoporosis, but there are very few studies on the ageing of the urogenital system [1].

Urinary incontinence in women is defined as involuntary leakage of urine [2]. Since 1998, the International Continence Society (the ICS) has described urinary incontinence as situation in which involuntary urination causes a social or hygienic problem and it is objectively visible. When we define urinary incontinence like this, sporadic episodes of lack of urination control do not fall under the category of incontinence [3].

In 2002, the ICS published an updated and improved report on the correct terminology according to which urinary incontinence is a symptom, which manifests itself in an involuntary leakage of urine. Currently, the patient's report is the most important element in establishing the existence of the problem, whereas the circumstances associated with the leakage, its severity and the impact it has on the quality of life are factors that help to establish a more precise diagnosis. The new definition describes urinary incontinence as a symptom rather than a disease $[2,4]$.

Urinary incontinence is not only a medical problem, but also a sociopsychological one. People affected by it withdraw from social life and limit their going out. Urinary incontinence is often responsible for sexual disorders and, as a consequence, for refraining from having sex. In extreme cases, it can lead to social isolation and depression [5].

The exact number of cases of women suffering from urinary incontinence is not known due to the feelings of 
shame, embarrassment and women's unwillingness to talk about during doctor's appointment [3].

Depending on the definition one uses, it is estimated that $17-60 \%$ of women suffer from urinary incontinence [6]. In Poland, this problem affects 2-3 million women. It is estimated that around $50 \%$ of women were dealing with urinary incontinence at some point in their lives [7]. As regards women who undergo menopause the number is $33 \%$ [8].

\section{Classification}

There is no single, unified urinary incontinence classification in medical literature. Most commonly we distinguish stress incontinence, urge incontinence and mixed incontinence. A more detailed classification distinguishes symptoms of overflow incontinence, chronic (passive and reflexive) incontinence, enuresis and urinary incontinence due to other causes, e.g. constipation, urinary tract infection, fear, estrogen deficiency $[3,9]$.

The malfunction of the closing system in the urinary bladder results in stress incontinence, responding to the increase in the intra-abdominal pressure due to cough, laughter or change in the position of the body. It is the most common form of urinary incontinence (60\% of the affected), caused by excessive stretching or flaccidity of supporting structures in urethra or bladder neck and by the weakness of pelvic floor muscles. Stress incontinence is especially common among women who are diagnosed with pelvic organ prolapse or who are over 50, due to hormone deficiency $[3,10,11]$.

Urge incontinence is an involuntary loss of urine due to a feeling of sudden need or urge to urinate. $25 \%$ of all incontinence sufferers have this particular form of the disorder, but its prevalence increases among women after menopause and in the old age [3].

Overflow incontinence is characterized by a dripping urine leakage due to overly full urinary bladder and a significant stretching of bladder's walls [11]. This disorder is caused by chronic urine retention. Bladder's adaptive limits are breached which causes the urine to leak. This is caused by compromised bladder's contractility, e.g. reduced strength or a blockage if the urine flows. Overflow incontinence is diagnosed in elderly women due to detrusor urinae muscle's hypotonia [9].

Chronic urinary incontinence can occur as a result of many circumstances. If the patient is aware that she is leaking urine, the incontinence might be caused by the damage or degeneration of a constrictor muscle. If urine leaks without a conscious decision on the part of the patient, the cause might be the damage of the central nervous system due to disease, accident, injuries and spina bifida, cerebral arteriosclerosis or stroke. Functional, passive urinary incontinence can also occur as a result of mental and emotional disorders, amentia, sleepiness, permanent immobility, physical disability or consumption of sedative or anxiolytic drugs [3].

\section{Menopause and age and urinary incontinence}

Undisturbed ageing should not be the cause of urinary incontinence. Urinary incontinence is always a pathology and requires diagnosis and treatment. The genitourinary system gets old just as the rest of the body [12]. When talking about urinary incontinence in women after menopause, attention needs to be drawn to the changes in the area of pelvic organs [8]. The lower parts of the urinary system and sex organs have a common origin in embryogenesis - the urogenital sinus [1]. The anatomic closeness and the common origin of these two systems is a sufficient reason to consider the urinary system and the genital system together. The biggest problem is to establish whether urinary incontinence in older women is caused by menopause-related changes or by the age [8].

During menopause, the concentration of estrogens is significantly lowered which often results in distinctive angiokinetic symptoms: hot flashes and night sweats. Estrogen and progesterone receptors are found in structures such as: vagina, urethra, urinary bladder and pelvic floor muscles [1]. Moreover, estrogen receptors are present in cortical centers, pons (two important centers responsible for urination) and in the fore-brain. A low concentration of ovarian sex hormones occurring during menopause leads to atrophic changes in the area of reproductive organs, structures of the pelvis minor's floor and in the lower urinary tract $[8,13]$.

Urinary incontinence in older women can be caused by so-called mechanical changes. Factors causing and aggravating urinary incontinence include [1, 14-17]:

- obesity (body mass index - BMI > 30),

- chronic constipation/diarrhea,

- childbirth (especially numerous ones and the ones that involve large babies),

- fast course of the second part of the childbirth,

- gynecological procedures (e.g. hysterectomy),

- radiotherapy of the pelvis,

- chronic diseases involving coughing (e.g. asthma, chronic obstructive pulmonary disease),

- urinary tract infections

- taking certain drugs (diuretics, anxiolytics, antihypertensives)

- diabetes

- hypertension

- neurological and psychiatric disorders such as stroke, Parkinson's disease, dementia, depression

- limited physical ability and smoking (smoking stimulates estrogens)

- overload due to weight lifting.

It is believed that women performing advanced endurance sports are at a risk of developing urinary incon- 
tinence. Less potent symptoms of urinary incontinence are found in women who regularly exercise with moderate intensity [18].

There are many studies in which authors do not see any link between urinary incontinence and menopause. According to Australian researchers, urinary incontinence in mature women is not a result of hormonal changes but rather it is caused by collagen deficiency in fascial structures and by the weakening of pelvic ligaments, which results in pelvic organ prolapse and incontinence [16]. According to Swanson et al., age is not a risk factor as far as urinary incontinence is concerned. Based upon data gathered from 1082 women, aged 45 and older, the researchers linked urinary incontinence to earlier factors such as: chronic cough, constipation, lower limbs edema, childbirth, obesity and smoking. Factors linked to stress incontinence included: chronic cough and smoking. Constipation and lower limbs edema (a result of little physical activity) were considered to be a risk factor for urge incontinence [14].

A study performed on 82 healthy nulliparous women by Trowbridge et al. showed that the following elements did not depend on the age of the study subjects: the extent of pelvic organs' and urethra's support, the activity of elevator muscle of anus and the strength of colpospasm during resting. The only age-related change that was occurring in the urinary system was the reduction in maximum urethral closure pressure of $15 \mathrm{~cm} \mathrm{H}_{2} \mathrm{O}$ with each decade, between the age 21 and 70 [19].

Milsom compared urinary incontinence prevalence among women before and women after menopause. Urinary incontinence prevalence in both groups was estimated to be around $12 \%$ and this demonstrated that menopause had no influence on the functions of the lower urinary tract [20]. Six years' questionnaire study by Waetien et al. showed neither increase nor increase in the symptoms of urinary incontinence associated with age in post-menopausal female participants [21]. According to Mishra et al., menopause and the associated body changes can only be linked to stress incontinence. In their study they showed that the biggest increase in the symptoms of stress incontinence was present in premenopausal women. The age and childhood incontinence were considered risk factors for urge incontinence. Obesity was linked to both urge and stress incontinence [22]. Valentini et al. carried out urodynamic tests on over 400 post-menopausal women. There were three subgroups. The first group consisted of women aged 55-64, the second group consisted of women aged 65-74 and the third group consisted of women aged 75-93. In most of the cases $(66.3 \%)$ the test was performed due to urinary incontinence. The results showed that the age was a risk factor for mixed incontinence which, researchers think, is explained by impaired functioning of urethral sphincter muscle and the hyperreactivity of the bladder. The deterioration of detrusor urinae muscle and hyperactive blad- der were the most common diagnoses in the third age group. The urge incontinence was not linked to age in any way [23]. Different perspective comes from a study by Findink et al., who established that urge incontinence is most prevalent among women after menopause [24].

\section{Physiotherapeutic conduct}

Following the recommendations of the Polish Gynecological Society regarding the diagnosis and treatment of urinary incontinence in women (Poznań, 20 September 2005), the basis for starting the treatment is initial diagnosis of the type of the incontinence (stress incontinence, urge incontinence and mixed incontinence) [25]. Effective treatment depends on an adequate diagnosis but also on the involvement and consistency on the part of the patient and the doctor [26].

Physiotherapeutic methods most commonly used in the treatment of urinary incontinence include: urogenital diaphragm exercises (Kegel exercise), behavior therapy (biofeedback, bladder training), electrostimulation, magnetic therapy and vaginal cones [27].

- Urogenital diaphragm exercises - exercises for pelvic floor muscles should be directed at improving sensomotor functioning, durability, strength and speed of the cramp and the ability of coordination (activity and relaxation of pelvic floor muscles, muscle activation, e.g. before coughing) [18].

- Biofeedback - a method of biological feedback which involves the learning of conscious stretching and relaxation of pelvic floor muscles. This method should be used in patients who can stretch muscles in an isolated way or patients whose muscle strength is very small [18]. Apparatuses required in biofeedback consist of a module gathering data on the work of "undesirable" muscles (adductor muscle), a module for transferring the data and a module for processing the data into visual or audio signals. A patient performing a contraction sees a screen with a chart showing the work of her muscles. By seeing the chart she can exert an influence by contracting and relaxing harder and by contracting the muscles of the pelvic floor with more precision (Fig. 1.) [27, 28].

- Electrostimulation - an effective method of treatment of stress incontinence, urge incontinence and mixed incontinence. Electrostimulation causes contraction in the external urethral sphincter and in the levator, causing the neck of urinary bladder to lift up, which extends the urethra. The innervations running from pudendal nerves to the spinal cord's segments S2-S4 improve the functioning of this reflex pathway. All this strengthens the muscles of the pelvic floor which had previously been weakened and deprived of their functioning [26].

- Bladder training - bladder exercises involve urinating at a specific time, not when one feels the urge 
to urinate. The training means extending the periods between mictions [27].

- Magnetic fields - the procedure is painless. A patient is sitting, fully clothed, in a chair which is a source of the magnetic field. Stimulation involves two $20 \mathrm{~min}$ utes' sessions a week and lasts for 5-8 weeks [27].

- Vaginal cones - keeping the cones in vagina requires clamping the pelvic floor muscles and moving the cones upwards so that they do not fall out [27].

Research by $B \varnothing$ et al. emphasized the superiority of Kegel exercises over electrostimulation and vaginal cones in the treatment of stress incontinence. Both the muscle strength measurement by vaginal catheter and the sanitary napkin test showed that the best results were achieved by women who stretched Kegel muscles on their own [29].

\section{Pelvic floor muscles exercises}

Pelvic floor muscles exercises to be effective have to follow several rules. Kegel exercises are characterized by three terms: burdening, specificity and reversibility. Correctly performed Kegel exercises cause - among other thing - an increase in the number of mitochondria, increased activity of aerobic and anaerobic enzymes, increased glycogen levels and increased blood supply. To strengthen the muscles at the bottom of the pelvis, they have to be burdened with 10-11 seconds' contractions. A patient should generate the strength of contractions reaching $80 \%$ of her abilities. Specificity means that the muscles should be trained in the most physiological situations which are most characteristic of any given person, e.g. a marathon runner should constrict the muscles during running. Reversibility means that the effects of the training will fade away if the patient does not include the exercises in her daily routines [30].

Finding Kegel muscles can be a challenge for a lot of women. One of the ways of finding the muscles is to stop the stream of flowing urine. Proper Kegel exercise involves flexing and stopping the contraction of the muscles for a couple of seconds. Relaxation of the muscles should be as long as flexing them. Gradual extending of the contraction, from 1 to 10 seconds, is advised [12]. During the exercises one can use belly breathing as well as side rib breathing, both used in Pilates. No matter which method of breathing one adopts, the most important thing is to perform muscle flexion during exhaling [27].

It is still debated whether during pelvic floor muscle training one should flex abdominal muscles as well. Most researchers advise that during flexing Kegel muscles one should shut down the working of the following muscles: gluteus maximus, adductors and abdominal muscles. Synergistic work of transversus abdominis muscle with pelvic floor muscles was observed. It is advised that transversus abdominis muscle training be included in the pelvic floor muscles training, or be used independently by women with stress incontinence [18]. Eliminating abdominal press from

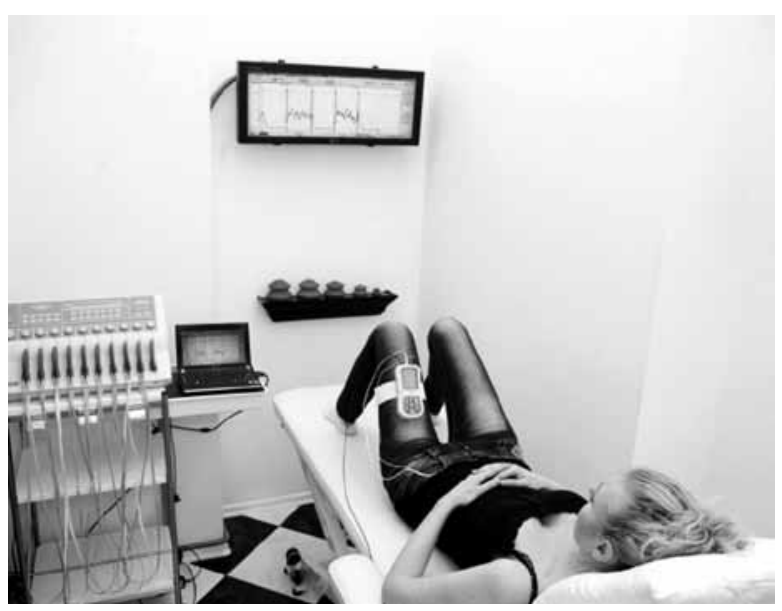

Fig. 1. Biofeedback of the pelvic floor muscles

the initial phase of the exercises is an optimal solution. If the patient learns to flex pelvic floor muscles properly, it is only then that one can introduce simultaneous exercises of abdominal muscles, adductors and gluteal muscles. The next level of exercises includes performing the exercises mentioned above in situations involving loading, such as cough, weight bearing and doing sports [27].

It is advised that the pelvic floor muscles exercises be performed individually. The training should last from 1 week to 6 months but in most cases 3 months' training is advised [55]. Depending on the author, from 8-12 rounds 3 times a day to 20 rounds 4 times a day are advised. Arthur Kegel - who developed Kegel exercises - advised up to 500 rounds a day. To experience improvement in urinary incontinence one might wait around 5 months into training. According to other sources, the exercises should be done 3-4 times a week and the improvement can be expected after 4-8 weeks of systematic training [18].

\section{Applying the right treatment in various urinary incontinences}

In stress incontinence the following methods are used $[1,25]$ :

- kegel exercise,

- vaginal electrostimulation,

- bladder training,

- vaginal cones,

- vibration training on a vibration platform,

- estrogen therapy.

In urge incontinence the following methods are used

$[1,27]$ :

- vaginal electrostimulation,

- functional magnetic stimulation,

- bladder training,

- estrogen therapy,

- antimuscarinic drugs. 


\section{Prophylaxis}

The role of the patient should cover changes in her lifestyle: limiting smoking, weight bearing and preventing infections in the urinary tract. The role of the doctor is to effectively treat the infections of the urinary tract, apply hormone replacement therapy during menopause and assisting in a delivery without prolonging stage II of the childbirth [1].

Information about urinary incontinence should be more readily available in the country and cities. Television, the Internet and friends are the main source of knowledge on urinary incontinence. Only a small group of women seeks information about this issue from their gynecologist and GP [15].

\section{References}

1. Darewicz B, Skrodzka M, Kudelski J. Problemy urologiczne kobiet okresu pomenopauzalnego. Prz Menopauz 2008; 12: 175-83.

2. Borówka A. Problem nietrzymania moczu w ocenie Konsultanta Krajowego w dziedzinie urologii. Przegl Urol 2003, 3: 60-0.

3. Jolleys J. Nietrzymanie moczu. W: Problemy zdrowotne kobiet. McPherson A (ed.). PWN Springer, Warszawa 1997; 310-34.

4. Adamiak A, Jankiewicz K. Epidemiologia nietrzymania moczu. In: Nietrzymanie moczu i zaburzenia statyki dna miednicy u kobiet. Rechberger T (ed.). Termedia, Poznań 2009; 19-25.

5. Pypno W. Problemy urologiczne u osób w wieku podeszłym. In: Geriatria. Wybrane zagadnienia. Galus K (ed.). Elsevier Urban \& Partner, Wrocław 2007; 93-111.

6. Rechberger T, Skorupski P. Wprowadzenie. In: Nietrzymanie moczu u kobiet. Rechberger T, Jakowicki JA (eds.). Wyd. BiFolium, Lublin 2005; 13-21.

7. Radziszewski P, Dobroński P. Co to jest nietrzymanie moczu. In: Nietrzymanie moczu. Radziszewski P, Dobroński P (eds.). Wydawnictwo Lekarskie PZWL, Warszawa 2008; 16-27.

8. Pertyński T, Stachowiak G. Menopauza jako czynnik ryzyka nietrzymania moczu u kobiet. In: Nietrzymanie moczu u kobiet. Rechberger T, Jakowicki JA (eds.). Wyd. BiFolium, Lublin 2005; 95-105.

9. Dadej R, Kwias Z, Cieśliński P. Wysiłkowe nietrzymanie moczu. In: Ginekologia. Stomko Z (ed.). Wydawnictwo Lekarskie PZWL, Warszawa 2008; 1180-7.

10. Pisarski T, Skrzypczak T. Urologia ginekologiczna. In: Położnictwo i ginekologia. Pisarski T (ed.). Wydawnictwo Lekarskie PZWL, Warszawa 1998; 821-30.

11. Klisowska I, Dąbek A, Zborowska I, et al. Nietrzymanie moczu - zadanie dla fizjoterapeuty. Część II. Piel Zdr Publ 2012; 2: 145-52.

12. Ackermann R. Choroby dróg moczowych. In: Geriatria. Rosenthal T, Nughton B, Williams M (eds.). Czelej, Lublin 2009; 213-39.
13. Jóźwik M, Jóźwik M, Pietrzycki B. Niestabilność mięśnia wypieracza jako objaw menopauzy. Prz Menopauz 2003; 3: 46-53.

14. Swanson JG, Kaczorowski J, Skelly J, Finkelstein M. Urinary incontinence - common problem among women over 45. Can Fam Physician 2005; 51: 84-5.

15. Derewiecki T, Duda M, Majcher P, Mroczek K. Wiedza kobiet na temat nietrzymania moczu i sposobów radzenia sobie z chorobą. Zdr Publ 2012; 122: 269-73.

16. Sherburn M, Guthrie JR, Dudley EC, et al. Is incontinence associated with menopause? Obstet Gynecol 2001; 98: 628-33.

17. Sampselle CM, Harlow SD, Skurnick J, et al. Urinary incontinence predictors and life impact in ethnically diverse perimenopausal women. Obstet Gynecol 2002; 100: 1230-8.

18. Chmielewska D, Kwaśna K, Piecha M, et al. Wybrane metody zachowawczego leczenia wysiłkowego nietrzymania moczu - aktualne poglądy. Część 1. Prz Menopauz 2012; 16: 264-8.

19. Trowbridge ER, Wei JT, Fenner DE, et al. Effects of aging on lower urinary tract and pelvic floor function in nulliparous women. Obstet Gynecol 2007; 109: 715-20.

20. Milsom I, Ekelund P, Molander U, et al. The influence of age, parity, oral contraception, hysterectomy and menopause on the prevalence of urinary incontinence in women. J Urol 1993; 149: 1459-62.

21. Waetjen LE, Feng WY, Ye J, et al; Study of Women's Health Across the Nation (SWAN).Factors associated with worsening and improving urinary incontinence across the menopausal transition. Obstet Gynecol 2008; 111: 667-77.

22. Mishra GD, Cardozo L, Kuh D. Menopausal transition and the risk of urinary incontinence: results from a British prospective cohort. BJU Int 2010; 106: 1170-5.

23. Valentini FA, Robain G, Marti BG. Urodynamics in women from menopause to oldest age: what motive? What diagnosis? Int Braz J Urol 2011; 37: 100-7.

24. Findik RB, Unluer AN, Sahin E, et al. Urinary incontinence in women and its relation with pregnancy, mode of delivery, connective tissue disease and other factors. Adv Clin Exp Med 2012; 21: 207-13.

25. Kwaśna K, Chmielewska D, Piecha $M$, et al. Wybrane metody zachowawczego leczenia wysiłkowego nietrzymania moczu - metody fizjoterapeutyczne, część 2. Prz Menopauz 2012; 16: 372-5.

26. Gałczyński K, Romanek K, Kulik-Rechberger B, Rechberger T. Elektrostymulacja mięśni dna miednicy w leczeniu nietrzymania moczu u kobiet. Prz Menopauz 2011; 15: 427-43.

27. Borowicz AM, Wieczorowska-Tobis K. Metody fizjoterapeutyczne w leczeniu nietrzymania moczu. Gerontol Pol 2010; 18: 114-9.

28. Basista P. Biofeedback - skuteczna rehabilitacja NTM. Kwartalnik NTM 2013; 1: 6-8

29. Bø K, Talseth T, Holme I., Single blind, randomised controlled trial of pelvic floor exercises, electrical stimulation, vaginal cones, and no treatment in management of genuine stress incontinence in women. BMJ 1999; 318: 487-93.

30. Marques A, Stothers L, Macnab A. The status of pelvic floor muscle training for women. Can Urol Assoc J 2010; 4: 419-24. 